\title{
Othello entre gêneros
}

Roberto Moreira $\overline{\text { ECA-USP }}$ 


\section{Resumo}

O texto analisa como, no Othello de Shakespeare, em torno do personagem Iago se articula uma reflexão sobre a tragédia clássica e o ainda incipiente gênero do melodrama.

\section{Palavras-chave}

Shakespeare, tragédia, melodrama, gêneros dramáticos

\section{Abstract:}

The text analyses how, in Shakespeare's Othello, a reflection upon classic tragedy and the still newborn genre of melodrama is built around Iago's character.

\section{Keywords}

Shakespeare, tragedy, melodrama, dramatic genres. 


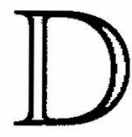
esenhar a fronteira entre tragédia e melodrama é difícil. O trágico não é um, mas vários: cada autor teatral, cada filósofo ou crítico possui uma definição diferente.' Tal dificuldade conceitual do trágico não pode ser atribuída a uma insuficiência crítica, mas sim a uma questão que toca na essência mesma do conceito. Já ao melodrama associamos filmes, livros e novelas de televisão de fácil apelo sentimental, personagens esquemáticos e tramas convencionais. Assim, o descartamos como banal e indigno de atenção. No entanto, os textos que podemos definir como trágicos ou melodramáticos partilham inúmeras características: são gêneros sérios, que propõem ao espectador uma experiência intensa, muitas vezes dolorosa e movimentam, todos os dois, conflitos de ordem moral. Os dois gêneros são respostas diferentes a problemas semelhantes.

Em The Melodramatic Imagination (1995) o melodrama é analisado como uma modalidade definidora da imaginação ocidental a partir do século XVIII. Sua primeira característica é a luta entre bem e mal que está encarnada em dois personagens caracterizados sem nenhuma sutileza: a jovem heroína que representa a virtude versus o traiçoeiro e dissimulado vilão. Na maior parte do tempo o mal reina triunfante, controlando a estrutura dos acontecimentos e ditando as coordenadas morais da realidade. A vitória final da virtude não é uma regra absoluta. $O$ mais importante é indicar a presença e modo de operação do bem e do mal no mundo, tornando evidente,

1. Um rica investigação das variações no tratamento do conceito de trágico pela filosofia alemã pode ser encontrada em Peter Szondi, Saggio sul tragico (1996). 
legível, a escolha entre esses modos de ser. A função das peripécias e golpes de teatro é justamente fornecer a oportunidade para os personagens nomearem os atributos morais absolutos do universo e posicionarem-se em relação a eles. No melodrama os personagens emitem explicitamente seus julgamentos morais em relação ao mundo. "Nothing is understood, all is overstated." (Brooks, 1995: p.41).

A busca melodramática de intensidade emocional é complementar à recusa das convenções sociais, as quais ocultam o real caráter das personagens. Do mesmo modo, a recusa de um teatro da palavra, convencional, como o teatro clássico, corresponde à valorização do palco como um tableau plástico, um espaço para os sentidos visuais.

O melodrama tenta indicar um sentido que ultrapassa a experiência cotidiana, que está além, ou por trás, dos objetos e homens. Como afirma Brooks, é a modalidade do excesso: a postulação de um significado que excede as possibilidades do significante, um texto que indica sentidos amplos (por exemplo, a graça divina) que nunca será capaz de alcançar. Seus gestos, falas e ações são metáforas. O lugar onde está localizado o sentido latente é o espaço do oculto moral, o domínio dos valores espirituais que está, ao mesmo tempo, indicado dentro e mascarado pela superfície da realidade. $O$ oculto moral não é um sistema metafísico, mas sim o repositório dos restos dessacralizados e fragmentários do sagrado. Ele pode ser comparado ao inconsciente, pois trata-se de uma esfera do ser onde nossos desejos e interdições mais básicas residem, um lugar que na nossa existência cotidiana parece inalcançável, mas ao qual devemos ascender pois é o domínio do sentido e do valor. A modalidade do melodrama existe em larga medida para localizar e articular o oculto moral oferecendo um universo legível para aqueles que desejam ver e interpretar corretamente os seus signos.

Em linhas gerais este é o sentido da argumentação do livro. Para Brooks, o melodrama procura construir significados para um mundo dessacralizado, incapaz de dar sentido a existência.

Ao contrário de Brooks, Robert B. Heilman (1968) caracterizou o melodrama e a tragédia como duas categorias atemporais. A sensibilidade melodramática não surge apenas com a 
Revolução Francesa, mas é uma modalidade do ser. Na tragédia temos personagens divididos:

In tragic life, man may feel competing loyalties; aspire to virtue or pursue a noble end, and be betrayed by a passion; seek an evil end, and be betrayed by undismissable good; or try to fill one need, and find that another blocks his course. (Heilman, 1968: p.14)

Compelidos a realizar escolhas, os personagens trágicos desenvolvem alguma consciência sobre a situação em que estão inseridos e, ao agir, sabem e assumem plenamente as conseqüências de seus atos. São personagens inteligentes e fortes cujas escolhas são, ao mesmo tempo, uma afirmação de si e um suicídio. No melodrama, ao contrário, o personagem é coeso e a origem do conflito externa. O protagonista é uma vítima, seja da sociedade, da natureza, de um vilão ou de si mesmo.

Atualmente, o melodrama parece estar em todos os lugares. A partir das análises de Heilman e Brooks é possível afirmar que o cinema clássico americano é intrinsecamente melodramático. Personagens como Indiana Jones ${ }^{2}$ Michael $^{3}$ ou Travis ${ }^{4}$ não são divididos e conscientes de suas escolhas. Todos ocupam a posição de vitimas. Quando o ponto de partida é um conflito interno, como em Tootsie ou Taxi Driver, ao final a personagem reencontra a unidade perdida, exibindo essa completude apontada por Heilman e definida por Bordwell como uma característica do cinema clássico americano. O seu conflito não implica uma escolha, ou seja, uma opção consciente entre termos igualmente válidos. Ao contrário, Michael e Travis, de modo desastrado e impulsivo conseguem expelir um invasor que os vitimizava, reconquistando sua unidade. Eles se tornam "bons" e purgam o "mal" que os invadia, dotando de sentido

2. Protagonista de Indiana Jones

3. Protagonista de Tootsie

4. Protagonista de Taxi Driver 
a sua existência. O processo vitimizador é tão disseminado na dramaturgia ocidental que tornou-se imperceptível e pode ser encontrado nas modalidades mais "altas" ou "baixas" da cultura. Heilman caracteriza uma importante vertente da dramaturgia moderna, da qual fazem parte tanto Beckett quanto O'Neill, como uma literatura do desespero que coloca em cena "the disaster of the self".(Helman, 1968: p.56) Como aponta Ismail Xavier (2000), esse processo vitimizador presta-se a ficções de esquerda e direita e é também difundido na mídia contemporânea. $\mathrm{O}$ apelo visual aliado ao maniqueísmo das forças em conflito presta-se com perfeição a este processo de espetacularização do cotidiano que caracteriza o telejornalismo.

Para comprender o que não é melodramático é preciso deterse sobre textos anteriores ao século XIX. A análise que segue pretende discutir como o melodramático e o trágico aparecem simultâneamente em Othello. Esse caráter híbrido e complexo do texto exige uma caracterização precisa dos conceitos.

Os aspectos melodramáticos da peça são:

- A virtude perseguida. Desdêmona encarna com perfeição a vítima inocente e mesmo Othello pode ser considerado uma vítima das maquinações de Iago.

- Os personagens esquemáticos: Desdêmona é fiel a si mesma do começo ao fim, sua última fala é a melhor prova. Também Othello apresenta poucas variações. Trata-se de um altivo guerreiro, portanto, o uso da violência está integrado ao seu personagem. A mudança, mais de uma vez evocada como trágica (sua serenidade após o assassinato de Desdêmona) é psicologicamente coerente. Estamos longe aqui de um Macbeth ou Hamlet que continuamente refletem sobre seus ato ou de Édipo cuja anagnorisis lhe desvenda aspectos que ignorava de si mesmo.

- É um drama doméstico. No centro da trama não há nenhum reino usurpado, mas sim os ciúmes de um soldado pela sua esposa. 
- A passividade dos protagonistas aproxima a peça da estrutura do pesadelo. ${ }^{5}$ É um comentário comum ${ }^{6}$ o mal-estar provocado pelo texto justamente porque o amor de Othello e Desdêmona levam ao extremo o engano criado por Iago. Os dois estão a um passo da verdade, mas ela escapa continuamente. A importância da intriga diminui a responsabilidade dos personagens, acentuando a sensação de não existirem alternativas. A fatalidade toma o partido do mal. Tudo parece favorecer as intrigas de Iago.?

- A peripécia é uma oportunidade para os personagens se identificarem moralmente. Os qüiproquós da peça aumentam a intensidade do momento em que a identidade moral dos personagens é plenamente estabelecida ao final da peça. ${ }^{8}$

- Didatismo moral: Desdêmona é uma vítima tão passiva que nem chega a comprender que é perseguida. No entanto, ao final, sua integridade moral vence a confusão gerada por Iago. Ela esclarece e torna inteligível os absolutos éticos em jogo no texto. ${ }^{9}$

5. "Subjected to horror, virtue must undergo an experience of the unbearable. Melodrama is similar to tragedy in asking us to endure the extremes of pain and anguish. It differs in constantly reaching toward the "too much," and in the passivity of response to anguish, so that we accede to the experience of nightmare (...). The familial structure that melodrama (like Greek tragedy) so often exploits contributes to the experience of excruciation: the most basic loyalties and relationships become a source of torture". (Brooks, 1995: p.35.)

6. "I am glad I have ended my revisal of this dreadful scene. It is not to be endured", Johnson, Notes to Shakespeare, in: Johnson: Prose and Poetry, seleção de Mona Wilson (Londres: Rupert Hart-Davis, 1969) 621. "Of all Shakespeare's tragedies (...) Othello is the most painfully exciting and the most terrible." A. C. Bradley, 1965: p.148). Shakespearean Tragedy: Hamlet, Othello, King Lear, Macbeth (Greenwich: Premier, 1965) 148. "... those feelings of oppression, of confinement to a comparatively narrow world, and of dark fatality, which haunt us in reading Othello", ibid., 151. M. C. Bradbrook, The Living Monument: Shakespeare and the Theater of his Time (Cambridge: Cambridge University Press, 1976) 163, comenta a sensação de horror que causava a Voltaire o assassinato de Desdêmona no seu leito.

7. Bradbrook, Living Monument, 163.

8. Bradley, Shakesperean Tragedy, 153.

9. The peripeties and coup de théâtre so characteristic of melodrama frequently turn on the act of nomination or its equivalent, for the moment in which moral identity is stablished is most often one of dramatic intensity or reversal. (...) Melodrama needs a repeated use of peripety and coups de théâtre because it is here that characters are best in a position to name the absolute moral attributes of the universe, to say its nature as they proclaim their own. Brooks, Melodramatic Imagination, 39-40. 
- A mistura de alta e baixa cultura. Por exemplo, no uso da canção Willow, willow, willow.

- A morte de Desdêmona em seu leito nupcial, vestida de noiva, é um tableau acabado.

- Temos em Iago uma ótima encarnação do vilão. Dissimulado, traidor, intrigante e portador de um mal sem motivação clara são características tradicionalmente reconhecidas em Iago. ${ }^{10}$ Eis como Brooks descreve o personagem melodramático:

Opposed to virtue and innocence stands the active, concerted denial of them in the person of evil, know traditionally as le traître, no doubt because he dissimulates, but also because he betrays and undoes the moral order. Betrayal is a personal version of evil. ${ }^{11}$

If there is a typical discrepancy between motive and villainy, it is no doubt because evil in the world of melodrama does not need justification: it exists, simply. ${ }^{12}$

In the clash of virtue and villainy, it is the later that constitutes the active force and the motor of the plot. ${ }^{13}$

Apenas a personagem de Othello parece escapar ao melodrama. Robert Heilman chama a atenção para este aspecto:

Othello also appears to have closer affiliations with the literature of disaster, for throughout the play we have a villain victimizing the hero; it is almost as though Othello were overcome by an irresistible outer force or enemy, indeed, some critics see Othello as a pathetic victim of an evil man. If we take this view, we can hardly call the

10. Ibid., 52-53.

11. Ibid., 33.

12. Ibid., 33.

13. Ibid., 34. 
play tragedy. But we do not have to use some other generic term if we perceive two facts: Othello transcends the role of victim by chossing to act evilly, and even in bending to Iago's influence he is actually failing to control a part of himself rather than giving way under outside pressure. If this is true, then he acts in the tragic stile. Nevertheless a villain is there, and when there is a villain, we need to see whether he is the major source of evil visited upon others whom he victimises, or, on the other hand, objectifies or corresponds to a a prior, more fundamental source of evil in the "good man" or "hero" himself. The latter situation is tragic; the former is something else. ${ }^{14}$

Portanto, seria a divisão interna entre os impulsos de vingança e amor que impede Othello de assumir a completude característica das personagens melodramáticas. Esse é um ponto de vista problemático e aberto a interpretação. Para um guerreiro é natural expressar-se com violência, assim podemos considerar o personagem coerentemente impulsivo. A mesma força que o leva à paixão o induz ao assassinato. Sem a intervenção de Iago, provavelmente o amor do casal continuaria sua trajetória positiva. Nada indica que a semente da destruição está dentro de Othello e Desdêmona.

Mas a citação de Heilman também ilustra a angustia do crítico frente a um objeto inclassificável. O personagem Othello é trágico ou melodramático? Como se as obras fossem ilustrações dos gêneros, e não os gêneros categorias deduzidas das obras.

Othello realiza muito do projeto melodramático, principalmente ao personalizar os conflitos. Após matar Desdêmona, em vez de perceber (como Édipo, Orestes ou Fausto) seu ato como uma falha moral, Othello é tomado pelo arrependimento. "He feels

14. Heilman, Tragedy, 33. Conferir também Eric Bentley, The Life of Drama, (Atheneum: Nova York, 1967) 268. Segundo o autor existe uma divisão de responsabilidades entre os dois personagens que não permite considerar Othello uma vitima. 
less that he has incurred guilt than that he has made a bad mistake". ${ }^{15}$ Ele mesmo se coloca na posição de vítima ao comentar "The pity of it, Iago. The pity of it" ou na cena final, ao insistir na responsabilidade de Iago pela sua desgraça. ${ }^{16} \mathrm{Um}$ personagem plenamente trágico assume toda a responsabilidade pelos seus atos.

Concluímos, portanto, que nenhum dos personagens possui uma estatura realmente trágica. Mas estamos portanto frente a um melodrama? Não necessariamente. O título Othello desvia a atenção daquele que é de fato o personagem principal do drama: Iago. É ele o motor da ação e portanto o personagem responsável, aquele que enfrenta as consequências de seus atos. ${ }^{17}$ É o próprio Othello que se recusa a identificar Iago com o demônio, o que poderia livrá-lo de sua responsabilidade:

I look down towards his feet; but that's a fable.

If that thou be'st a devil, I cannot kill thee. ${ }^{18}$

O desfecho é um exemplo acabado de ironia trágica. ${ }^{19}$ Iago, o intrigante infalível fracassou: o desfecho das tramas que ele mesmo elaborou desvendam seu caráter traiçoeiro. A variável imprevisível foi justamente um sentimento que reiteradamente desprezou: o amor. Ele substimou a afeição de Emilia por Desdêmona.

Durante toda a peça fomos seduzidos pela habilidade de Iago, ainda que seja difícil admitir fascinação por um personagem tão desprezível. Por isso, evitamos reconhecer nele o personagem principal: nossas inclinações morais, o título da obra e as regras do gênero apontam para Othello.

15. Heilman, 12.

16. Ibid., 151.

17. "lago's plot is lago's character in action", Bradley, Shakespearean Tragedy, 150.

18. Todas as citações da peça são conforme Shakespeare, Othello, The New Cambridge Shakespeare, editado por Norman Sanders (Cambridge University Press: Cambridge, 1984) 5.2.283-284.

19. Richard G. Mouton, Shakespeare as a Dramatic Artist (New York: Dover Publications, Inc., 1966) 239. 
Não à toa Bradley dedicou a Iago tanta atenção. Toda a sua crítica pretende libertar Iago da definição melodramática transformando-o em um ser humano complexo. ${ }^{20}$ Uma das características do texto que logo chama a atenção é a insistência com que os personagens da peça consideram Iago honesto. Tamanho sucesso para sua hipocrisia só pode ser explicado pelo seu prodigioso autocontrole na dissimulação e a frieza de suas emoções, mas também por uma boa natureza superficial que nunca antes havia deixado se manifestar suas tendências criminosas. Por isso Iago compartilha a tragédia de Othello. Jamais agiu de modo reprovável e, mal suas forças interiores manifestam-se, ele é imediatamente destruído.

A grande objeção mantém-se: o que motiva as ações de Iago? Coleridge expressou esta dificuldade na expressão "the motive hunting of a motiveless malignity". ${ }^{21}$ Daí a ver Iago como uma alegoria do mal, como uma manifestação do mal em si mesmo, é um passo fácil que Bradley refuta com veemência. Também é um erro aceitar as razões que o próprio Iago enumera. A multiplicação de motivos indica a dificuldade da personagem em comprender qual a sua intenção. Segundo Bradley, seus três desejos inconscientes seriam: satisfazer seu senso de superioridade e de controle; pôr à prova suas habilidades numa empreitada perigosa e, finalmente, exercer sua capacidade criativa.

He is (...) an amateur of tragedy in real life; and, instead of employing his invention on imaginary characters or long forgotten incidents, he takes the bolder and more dangerous course of getting up his plot at home, casts the principal parts among his nearest friends and connections, and rehearses it in downright earnest, with steady nerves and unbated resolution. ${ }^{22}$

Essas características de Iago não são em si mesmas más: o personagem não pode ser reduzido a uma figura simbólica, o mal

20. Bradley, 177 e passim.

21. Citado por Bradley, 189.

22. Hazlitt citado em Bradley, 191. 
puro. Seu intelecto excepcional, sua vontade e perspicácia despertam uma admiração misturada a ódio e horror. Se o mal nele fosse absoluto, seria um monstro completamente indiferente à opinião dos outros, $o$ que não é verdade. Ainda que Iago busque conquistar essa indiferença, podemos discernir traços de consciência, vergonha e humanidade. Afinal, se ele não possuísse nenhum senso moral

...we should never have heard those soliloquies which so clearly betray his uneasiness and his unconscious desire to persuade himself that he has some excuse for the villainy he contemplates. These seem to be indubitable proofs that, against his will, lago is a little better than his creed. ${ }^{23}$

Mas a necessidade de Bradley construir Iago como um ser humano o impede de alcançar uma verdade mais profunda do personagem. Ele precisa integrar os vários elementos contraditórios de Iago em um todo coerente que oponha-se a simplificação do símbolo. No entanto, Iago não é um organismo, mas sim um personagem, uma construção do texto. Granville-Baker afirma que Iago é um ator melodramático inserido na vida real. ${ }^{24}$ Ainda assim, seu viés naturalista o desvia do âmago. Não existe apenas um Iago, e sim vários: "I am not what I am" (1.1.66).

O honesto Iago é a sua máscara social. Durante a peça todos os personagens (com exceção de Brabantio) tratam Iago com estima e deferência.

O vilão Iago é seu papel no melodrama vivido por Othello, Desdêmona e Emilia que, ao final, o nomeia vilão.

O trágico Iago (no mesmo sentido que podemos falar do trágico Sófocles) é o autor da trama que só o espectador presencia: "How? How? Let's see" 25 para concluir ao final "I haven't. It is

23. Bradley, 194.

24. Harley Granville-Baker, Prefaces to Shakespeare: Othello (B. T, Batsford: Londres, 1982) 115.

25. Othello, 5.2 .359 a 361 . 
engendered"26; " "Tis here, but yet confused" ou "Am I to put our Cassio in some action". ${ }^{27}$ Mas não se trata de uma trama qualquer que está sendo elaborada, e sim de uma tragédia. É isto que mobiliza e atiça Iago.

So will I turn her virtue into pitch, And out of her own goodness make the net That shall enmesh them all. ${ }^{28}$

Esta qualidade será reconhecida ao final por Ludovico que, apontando o corpo de Desdêmona, diz para Iago:

Look on the tragic loading of this bed:

This is thy work. The object poisons sight

Let it be hid.

[The bed-curtains are drawn.] $]^{29}$

Por fim, temos o narrador Iago, porta-voz de Shakespeare.

As where's that palace, whereinto foul things

Sometimes intrude not? Who has a breast so pure,

But some uncleanly apprehensions

Keep leets and law-days, and in session sit $^{30}$

Aqui o tom introspectivo indica uma reflexão do próprio Shakespeare. É como se o dramaturgo justificasse para si mesmo a gênese de criaturas tão abjetas como Iago ou Macbeth, ecoando a máxima de Terêncio: "Eu sou um homeme nada de humano meé estranho".

A estrutura em abismo do personagem Iago espelha-se na estrutura da peça. Nós acompanhamos três "encenações".

A primeira é aquela que Iago constrói para Othello em torno do adultério de Desdêmona. A cena de mímica presenciada por Othello

26. Othello, 1.3.376.

27. Othello 1.3.385.

28. Othello 1.3.326-328

29. Othello 2.3.52.

30. Othello 3.3.138-142. 
entre Cassio e Iago é um dos momentos fortes desse registro. ${ }^{31} \mathrm{Seu}$ ponto culminante é a afirmação de Othello apontando o leito: "there lies your niece" (5.2.200). Este seria um bom tableau final para o projeto original de Iago.

Mas logo em seguida, a intriga de Iago desmorona e Othello suicida-se caindo sobre o leito de Desdêmona. Ludovico fecha as cortinas. Segundo Tableau. Ainda que o desenlace tenha escapado a seu controle, Iago ainda é o responsável por esse final.

Por fim, Ludovico encerra propriamente a peça que estamos assistindo após a prisão de Iago. Tableau final. Essa estrutura coloca em questão qualquer pretensão a uma "realidade" da cena: existe sempre um contexto mais amplo que relativiza uma verdade anterior.

A sobreposição de diferentes registros na ficção, conduzida por Shakespeare e pelo próprio Iago, procura demonstrar como os eventos mais corriqueiros do dia-a-dia são determinados pelo ponto de vista de quem os descreve, tornando a fronteira entre ilusão e realidade tênue e arbitrária. Esse movimento que leva a apagar as diferenças entre fato e ficção corresponde na peça a várias instâncias em que as diferenças sociais são ignoradas. Iago reclama, com relação a promoção de Cassio:

Preferment goes by letter and affection, Not by the old gradation, where each second Stood heir to the first. ${ }^{32}$

Ou quando Iago ironicamente equipara-se a Brabantio.

\author{
Brabantio \\ Thou art a Villain. \\ Iago \\ You are a senator. ${ }^{33}$
}

31. É impossivel não recordar aqui a importância e ambiguidade da gestualidade no melodrama como descrita por Brooks, Melodramatic Imagination, 72.

32. Othello 1.1.36-38.

33. Othello 1.1.117. 
Como quem diz que essa é uma diferença irrelevante... É este mesmo Brabantio, ao comentar o casamento de Othello e Desdêmona, que chama a atenção para o perigo:

For if such actions may have passage free, Bondslaves and pagans shall our statesmen be. ${ }^{34}$

É essa a ameaça da união de Othello e Desdêmona. Eles estão separados por uma diferença de extração social e de raça. Abrir mão desta diferença pode levar a uma crise profunda da sociedade. Quando Iago encoraja Roderigo a gritar o nome de Brabantio, ele está conscientemente lançando as bases dessa crise:

Do, with like timorous accent and dire yell, As when, by night and negligence, the fire Is spied in populous cities. ${ }^{35}$

O fogo é uma boa imagem do modo como a crise das diferenças espalha-se rapidamente contaminando todas as instâncias e ganha dimensão cósmica com a tempestade que destrói a frota turca. Sua culminação dramática encontra-se na cena em que Othello descobre que Cassio tem a posse do lenço que havia dado de presente a Desdêmona. Ele ajoelha-se e jura que

My bloody thoughts with violent pace

Shall ne'er look back, he ne'er ebb to humble love till that a capable and wide revenge

Swallow them up. ${ }^{36}$

Em seguida, Iago também ajoelha-se e coloca-se a serviço do "wronged Othello". A disposição espacial dos dois personagens

34. Othello 1.2.98-99.

35. Othello 1.1,75-77.

36. Othello 3.3.458-461 
ajoelhados reforça a idéia de simetria. Neste pacto de sangue ("O, blood, blood, blood!") diversas linhas convergem e alcançam um desenlace. Aqui fica evidente como Iago é movido pela necessidade de igualar-se a Othello:

And nothing can or shall content my soul

Till I am evened with him, wife for wife; ${ }^{37}$

Othello abandona as características altivas que faziam dele um herói e entrega-se a trama de Iago. Os dois personagens possuem então a mesma estatura. Mas, nessa cena o processo de anulação das diferenças também permuta os papéis de lago e Desdêmona. Iago sempre realçou o caráter bestial da relação sexual entre Othello e Desdêmona, atitude que camufla um profundo ressentimento. $\mathrm{O}$ mesmo ciúme sente por Cassio.

If Cassio do remains,

He hath a daily beauty in his life

That makes me ugly. ${ }^{38}$

Antes de ajoelhar em frente a Othello, Iago acabara de inventar uma cena na qual dormia com Cassio quando

In sleep I heard him say, 'Sweet Desdemona, And then, sir, he would gripe and wring my hand, Cry,'O sweet creature!' and then kiss me hard, As if he pluck'd up kisses by the roots That grew upon my lips; then laid his leg

Over my thigh, and sighed, and kissed; and then Cried, Cursed fate that gave thee to the Moor!'39

37. Othello 2.1.279-280.

38. Othello 5.1.18-19

39. Othello 3.3.421-427.

Significação $29 \cdot 176$ 
Esta sugestão de homossexualismo indica que Iago rompe com uma diferença ainda mais perigosa. Ao final do juramento declara: "I am your own for ever". ${ }^{40}$

O primeiro momento do processo que transforma Othello no igual de Iago é o juramento: ele passa a dissimular suas emoções ("O hardness to dissemble!" ${ }^{41}$ ) e transforma-se em vilão. O absurdo da anulação das diferenças persiste nas imagens antitéticas durante o asssassinato de Desdêmona. "So sweet was ne'er so fatal." 42 "It strikes where it doth love." 43 "The death's unnatural that kills for loving.". ${ }^{44}$ Mas a incriminação foi tão bem orquestrada que ao final

Thou dost stone my heart,

And mak'st me call what I intend to do

A murder, which I thought a sacrifice. ${ }^{45}$

Esta é a culminação do processo de transformação de Desdêmona em uma prostituta completamente vazia de valor. A trama que a transformou em vítima subjugou completamente a capacidade de julgamento de Othello. Este é o processo descrito por Girard ${ }^{46}$ no engendramento da vítima sacrificial, onde a versão que autoriza o crime oculta a arbitrariedade do ato. Iago comenta esse deslocamento ao justificar a atitude agressiva de Othello em relação a Desdêmona:

\section{Iago}

The business of the stat does him offence,

And he does chide with you. ${ }^{47}$

40. Othello 3.3.480.

41. Othello 3.4.30.

42. Othello 5.2.20.

43. Othello 5.2.22.

44. Othello 5.20.43.

45. Othello 5.2.63-65. Esta afirmação de Othello parece corroborar a visão hegeliana da tragédia moderna como uma infração jurídica e não mais como o conflito entre imperativos morais igualmente válidos como na tragédia antiga. É apenas um assassinato, sem o conteúdo paradoxal do sacrificio.

46. Girard, René. La Violence et le sacré. Éditions Bernard Grasset, 1972.

47. Othello 4.2.165-164. 
Aparentemente essas justificativas são racionalizações que desviam da questão, quando na realidade apontam para uma verdade profunda do processo de vitimização da personagem. Uma outra passagem atesta o quanto Shakespeare estava consciente de tal processo.

\section{Casio}

O God, that men should put an enemy in their mouths to steel away their brains! That we should with joy, pleasance, revel and applause transform ourselves into beasts $4^{48}$

O confronto com Emilia ${ }^{49}$ onde sucedem-se em cascata as antíteses, cristaliza a convicção de Othello, ao mesmo tempo que anuncia a reviravolta. Logo em seguida, Othello passará a ser vitima de Iago, que, por sua vez, de honesto aos olhos da sociedade passa a vilão. "Who can control his fate?" ${ }^{50} \mathrm{~A}$ sucessão de reviravoltas ilustra a arbitrariedade da escolha da vitima sacrificial. Os papéis podem inverter-se continuamente.

Voltando à discussão dos diferentes gêneros: também a sua definição muda de acordo com o ponto de vista. Se a história é narrada do ponto de vista de Othello ou Desdêmona estamos frente a um melodrama. A trama armada por Iago é melodramática. No entanto, se nos distanciamos um pouco, o que não quer dizer assumir o ponto de vista de Iago, mas sim um que o inclua, passamos a ver uma tragédia. Em Othello este jogo de ponto de vista complica-se porque as qualidades do herói trágico encontram-se desdobradas em dois personagens, quando o valor e a responsabilidade são atributos, em geral, de uma mesma pessoa.

A intuição de Bentley parece se confirmar: "There is a melodrama in every tragedy". ${ }^{51}$ Como observou Girard toda tragédia é uma deconstrução parcial do mito, pois ao final, na reconciliação, o

48. Othello 2.3.265-267

49. Othello 5.2.130.

50. Othello 5.2.263.

51. Othello 5.2.263.

Significação $29 \cdot 178$ 
mito reafirma-se: Iago e Othello são castigados. Já o melodrama, com suas dicotomias maniqueístas, desde o início atualiza o mito. É a linguagem por excelência do discurso sacrificial. Brooks tem razão ao afirmar que o objetivo do melodrama é tornar o mundo legível. $\mathrm{O}$ conceito de tragédia é problemático justamente porque nesse gênero manifesta-se a dificuldade e arbitrariedade da constituição do sentido. Assim, é através do trágico que aflora o surgimento de uma consciência crítica em relação aos esquemas do sagrado.

\section{Bibliografía}

BRADBROOK, M.C. 1976. The Living Monument: Shakespeare and the Theater of his Time. Cambridge: Cambridge University Press.

BRADLEY, A. C. 1965. Shakespearean Tragedy: Hamlet, Othello, King Lear, Macbeth. Greenwich: Premier, 1965)

BROOKS, Peter. 1995. The Melodramatic Imagination. New Haven: Yaje University Press, $2^{a}$ Ed.

HEILMAN, Robert Bechtilold. 1968. Tragedy and Melodrama: Versions of Experience. Washington: University of Washington Press.

GIRARD, René. 1972. La Violence et le sacré. Paris: Éditions Bernard Grasset.

MOUTON, Richard G. 1966. Shakespeare as a Dramatic Artist. New York: Dover Publications, Inc.

SZONZI, Peter. 1996. Saggio sul trágico. Turim: Einaudi.

XAVIER, Ismail Norberto. 2000. "Melodrama, ou a Sedução da Moral Negociada", em Novos Estudos 57 (julho de 2000). 